Moving landscapes of Nordic basic education : Approaching shifting international influences through the narratives of educational experts

\author{
Hansen, Petteri
}

2020-08-17

Hansen , P , Wallenius , T , Juvonen , S \& Varjo , J 2020 , ' Moving landscapes of Nordic basic education: Approaching shifting international influences through the narratives of educational experts ' , Compare , vol. 50 , no. 6 , pp. 773-791 . https://doi.org/10.1080/03057925.2018.1557509

http://hdl.handle.net/10138/321767

https://doi.org/10.1080/03057925.2018.1557509

unspecified

acceptedVersion

Downloaded from Helda, University of Helsinki institutional repository.

This is an electronic reprint of the original article.

This reprint may differ from the original in pagination and typographic detail.

Please cite the original version. 
To cite this article: Petteri Hansen, Tommi Wallenius, Sara

Juvonen \& Janne Varjo (2020)

Moving landscapes of Nordic basic education: approaching

shifting international influences through

the narratives of educational experts, Compare: A Journal of

Comparative and International

Education, 50:6, 773-791

\title{
Moving landscapes of Nordic basic education: approaching shifting international influences through the narratives of educational experts
}

\author{
Petteri Hansen (D), Tommi Wallenius (D), Sara Juvonen (D) and Janne Varjo (iD) \\ Faculty of Educational sciences, University of Helsinki, Helsinki, Finland
}

\begin{abstract}
Throughout history educational leaders have looked to other countries and have attempted to learn by borrowing useful examples to implement in their own educational systems. As recent comparative policy research shows, processes of policy lending and borrowing have their own socio-historically defined dynamics. In this paper, the authors approach the use of reference countries through narratives of educational experts in Finland, Norway and Sweden. By comparing how international influences are used in stories about basic education, this research constructs a core narrative of a moving Nordic landscape. This landscape indicates both recognised and acknowledged policy borrowing relations in the past, as well as a changing orientation to preferred and avoided reference countries in the present. While new countryspecific performance indicators such as PISA have widened the landscape of reference countries at an official level, culturally mediated images seem to redefine how reference countries are observed in everyday semantics.
\end{abstract}

\section{KEYWORDS}

Nordic countries; basic education; systems theory; policy borrowing;

storytelling

\section{Introduction}

Despite its growing interdependence in the globalised world, education has remained a sector of relatively strong domestic policymaking. However, throughout history, educational leaders have looked to other countries and have attempted to learn from them and borrow useful examples to implement in their own educational systems. Recently, transnational organisations such as the Organisation for Economic Cooperation and Development (OECD) have become important mediators in the transmission of policies between countries. Global networks and especially international large-scale assessments have broadened the scope of educational policymakers to observe the whole globe.

Theorisation of the mechanisms behind this international exchange of ideas and practices has been a central topic in the field of comparative education research, and depending on their point of view, scholars have created several concepts to describe the processes, e.g. policy borrowing and lending (Steiner-Khamsi 2004), world culture convergence (Meyer et al. 1997) and soft governance (Moos 2009). One way to 
approach the question of legitimating national politics in a global environment is using the systems framework and concepts of 'externalisation' and 'reference societies' by Jürgen Schriewer (Schriewer 1990; Schriewer and Martinez 2004; Waldow 2017).

In this article, we investigate how reference societies are used to construct the story of basic education in Finland, Norway and Sweden. Narratives of the three case countries are interesting for two reasons. First, even though the Nordic countries - consisting of Denmark, Finland, Iceland, Norway and Sweden - are considered to share a mutual welfare-state model (Esping-Andersen 1990), the Nordic countries have had different strategies for coping and shaping transnational policy drifts. This particularly applies to policies relating to deregulation, privatisation and marketisation of comprehensive education (Dovemark et al. 2018). By contrasting the similarities and differences in national narratives, it becomes possible to understand the socio-historical dynamics of present education politics (Simola et al. 2017). Secondly, transnational assessment practices such as international PISA tests have changed the ways in which different societies observe each other by offering global projection screens for public discussion. In particular, Finland is often referred to in public discussion elsewhere as an ideal education country due to the high ranking and the relatively small differences in learning outcomes among Finnish students (Takayama 2010; Waldow 2017). There have also been a few studies focusing on how educational ideas have been silently borrowed in Sweden (Ringarp and Waldow 2016; Waldow 2009; Wermke and Höstfjä 2014). By focusing on how reference countries are used in stories of established policy actors in Finland, Norway and Sweden, this study aims to bring a new aspect on how images of the past and other countries are interlinked with our present understanding of the self and the future.

\section{Narratives as a form of self-observation}

Even though post-modern times have been characterised as the end of grand narratives, small and local narratives are still a powerful way to pass on ideas, attitudes and experiences (Lyotard 1979). Stories and narratives can thus be understood as an act of a meta-governance, through which social identities and forms of rationality can be reconstructed and transmitted in temporal situations without a clear presence of the governing body (Rhodes 2011; Sørensen 2006). In earlier research on Nordic educational governance, the narrative approach has been applied to describe how the urgency of educational reforms and the sensation of societal progress is created (Lindblad and Popkewitz 2000). However, the power of stories lies not only in the capacity of invoking change, but also in being capable of bringing the past into present, and in creating social continuity and collective identities. One should therefore pay careful attention to the temporal and self-referential nature of narratives. For this purpose, Niklas Luhmann's systems theory and the idea of the society as communication provides an interesting point of entry.

According to Luhmann (1995), the modern society has no external vantage point from which the unity of the world could be observed. Instead, the modern society makes itself understandable through functionally differentiated societal systems like politics, economics, law and education. Despite their operational closure, societal systems have organised sensitivity for other systems in their environment (Luhmann 1992). Moreover, social systems are able to use other systems as external points of reference in their own communication. 
Schriewer (1990) argues that educational subsystems are open to three forms of externalisation, namely, legitimation based on: 1) scientific impression; 2) similar/different values and culture; and 3) world situations. As Ringarp and Waldow (2016) suggest, externalisation by world situations could also be understood as a use of reference societies, indicating how socially constructed images of other communities (e.g. areas, countries and continents) are used to set goals and legitimise educational reforms both nationally and locally. This contemporary 'landscape' or social dimension of externalisation is constantly 'moving' in time as new reference societies emerge and as the images of the former reference societies change. Thus, the environment can be thought of as consisting of reference societies with several identities ranging from attractive to non-attractive, and even ones to avoid.

Even though Luhmann built his theory of social systems mainly on serious semantics in contrast to everyday observation (see Joas and Knöbl [2009]; Stäheli [1997]), systems theory can also be approached differently, namely as a diagnostic of the present. From this perspective, it becomes possible to observe how present understandings of social identities (us/them) and temporalities (past/present/future) are framing communicative expectations (Andersen 2003, 2013). When analysing the stories of educational experts in Finland, Norway and Sweden, our focus is not so much on historical consciousness of real historical happenings (Schieder 1978), but on how past happenings and the external environment are denoted to make sense and use in the present. By focusing on how social relations and temporality are constructed in present narratives of Nordic educational experts, this approach differs from similar studies based on a chronological concept of time and document analysis (cf. Ringarp and Waldow [2016]; Wermke and Höstfält [2014]).

From an epistemological perspective, expert narratives do not hold the same informative status as text documents that are considered to represent the serious semantics of system communication. In contrast to decisions or other written selfdescriptions, interviews represent the reflective side of system communication, namely self-observation. According to Stäheli (1997, 140-141), self-observations

establish a particular mode of observing the hegemonic mode of describing the systemic autopoiesis. In contrast to [...] self-description and its 'non-serious' counter-hegemonic re-articulations, these situational self-observations of a system do not add up to an alternative self-description, but they still re-iterate certain semantic patterns that are not necessarily part of the hegemonic self-description of a system.

In our research, stories are used particularly as present self-observations that (1) allow an observer to re-enact ${ }^{1}$ and reflect on past-present trajectories; (2) re-create social identities; and (3) both factualise and challenge hegemonic self-descriptions.

The analysis in this study is based on semantic analysis. Semantic analysis focuses on how different ideas, meanings and expectations are condensed into concepts offering a semantic reservoir and a frame for further communication. Luhmann (1995) points out three meaning dimensions of concepts. The social dimension refers to the constructive nature of social identities (us-them). The temporal dimension refers to the idea of a constantly moving present as a unity of difference between the past and the future. The factual dimension refers to how things are organised in relation to both other things and the social dimension (Andersen 2008). In our study, we have focused on these three dimensions of stories with two specific foci: first, we have looked at how the course of time (the temporal dimension) is used to describe the transformations in a national agenda setting 
(the factual dimension) of basic education policies. Our second focus has been on how external influences (the social dimension) are deployed to explain changes in the past as well when legitimising or resisting the emerging policies in the present. These dimensions are not separate but are utterly intertwined, thus the narratives operate as a projection between both past and present as well as present and future. ${ }^{2}$

\section{Research data}

The research data have been derived from analysis of 44 interviews conducted in 2015-2017: 9 in Finland, 17 in Sweden and 18 in Norway. The interviewees were a mixed but influential group of actors, among them many top-level politicians and policymakers, long-term civil servants, well-informed researchers and other important stakeholders. In order to identify key policy actors as well as ongoing debates, data collection started with a literature review and pilot interviews with established researchers. The selection of informants then followed the snowball sampling method (e.g. Noy [2008]), in which the informants are asked to suggest other relevant informants and organisations. We aimed to increase the validity of the selection criteria for informants by inviting persons who were mentioned or recommended by at least two previous interviewees.

The interviews were built around a single main question, 'What is the story of your country's basic education?' Interviewees were also given paper and a task to fill the empty timeline with most important happenings in the past. The interviewer also provided a translation and a national frame for the term comprehensive school (peruskoulu, grunnskole, grundskola) in order to focus the observation on the 9- to 10-year compulsory school form. The length of interviews varied from 30 minutes to two hours. It was considered that a minimalistic interviewing structure granted the informants as much freedom as possible for constructing their own storyline or narrative. If the interviewee did not mention anything on reference societies during the story, the question of possible international influences was asked after the story. The method provided space for 'natural narratives', but the freedom to choose the starting point of stories made the analysis and the comparison of the interviews more challenging. However, by reading through interviews multiple times with a focus on usage of international references, we were able to construct a core narrative through which different stories both complemented and challenged each other.

Another incoherency between the interviews was that the interviews in Finland were done in the Finnish language, while in Sweden and Norway most of the interviews were done by a foreigner and mainly in English. Even though the interviewees could use their own languages if they wanted - and which they did in five interviews - the stories would undoubtedly have been told differently to a fellow countryman or woman. Interviews were transcribed into the original language except in one case in which the transcriber also translated the interview. Both transcriptions and translations were checked afterwards.

\section{Framing the story of the comprehensive school}

People tend to describe the past with different intensity, which was also the case in this study. Some stories were told with a longer historical timespan and in more detail than others. The divergences in stories cannot be fully explained through different actor 
positions: in each country, there were policymakers who could reflect on the long sociohistorical genesis of their countries' comprehensive schooling. In order to construct a shared story from individual stories we first created country-specific timelines with a focus on international influences and changes in the agenda setting of basic education politics in different periods of time. After this, we compared the country-specific timelines and identified three transformation periods in which the use of the external environment was changing. These three transformation periods were entitled: (1) From folk education towards the comprehensive school model; (2) From pan-Nordic egalitarianism to the global knowledge economy; and (3) From PISA shock towards the delicate managing of future risks.

The three transformation periods based on interviews in all three countries are both overlapping and deviant with the time periods presented by previous research on the development of the Nordic education model. On the one hand the three transformation periods fit well into various historical descriptions on the development of basic education in Finland (Ahonen 2014), Norway (Imsen and Volckmar 2014) and Sweden (Blossing and Söderström 2014). In these studies, the most important milestones for further development of basic education are considered to be establishment of non-church organised folk education in the mid nineteenth century (Finland 1866, Norway 1889, Sweden 1842), comprehensive school reform in the 1960s (Finland 1968/1972, Norway 1954/1969, Sweden 1946/1962), decentralisation of school management in the 1980s and 1990s and increasing international influence since the beginning of the new millennium.

However, while the country-specific historical descriptions can define the specific dates for events and different time periods, it is impossible to require similar punctuality from narratives or to try to fit narratives from different countries within same time period. By replacing fixed time periods with the idea of transformation periods, we aim to capture both the ongoing nature and thickening of the stories for which the international influences and world situations provide external points of reference when explaining changes in the past. In addition, by presenting our country-specific analyses under three shared transformation periods instead of separate national narratives in their own sections, we wish to help the reader to perceive the relativity of the Nordic stories with many broad similarities in sense-making of the past, but also with some nuanced differences.

\section{From folk education towards the comprehensive school model}

While most of the informants started their stories after the Second World War, some interviewees set the first milestone in the mid-nineteenth century to indicate the birth of public education, also called folk education. In the Swedish narratives, organising folk education was presented as a joint project of the Protestant church and modernising the nation. The external influences during the folk education period were few: only when asked, some influences such as Grundtvigian ${ }^{3}$ ideas from Denmark concerning setting up nationwide education were confirmed. Later, when discussion focused on social democratic cooperation between Nordic countries at the turn of the century, the joint events were described as 'extremely big gatherings' (SWE I6).

For both Norway and Finland, the idea of compulsory folk education was introduced under foreign regimes (Sweden and Russia, respectively) in the 1860s, but these countries were not mentioned as having inspired influence. The few times when Russia was mentioned in 
Finnish stories, it was represented as an unwanted authoritative control regime. Instead, narratives emphasised that Finnish school reformers were seeking ideas from the West, mainly from Germany (or Prussia), in order to implement the Folk Education Act of 1866. However, the stories also emphasised the strong influence of the nationalistic Fennoman movement at the end of the nineteenth century, which aimed to strengthen the status of the Finnish language and culture. This movement was, however, influenced by German-speaking philosophers and the Finns started to adopt their thinking not only to foster the nationalistic movement and folkbildning (folk Bildung), but also to structure the common school system and teacher education.

As in Finland, folk education in Norway was also presented as a response to nation building and to providing at least some sort of education for children in rural areas. Among the individual countries, Denmark was considered to have played the most important part in the early formation phase of Norwegian basic education. Denmark was a place where Norwegian academics went to study and from where civil servants adopted ideas about organising folk education.

Entering the twentieth century, the Norwegian and Swedish narratives started to emphasise the importance of the Anglo-American world. For instance, John Dewey's ideas of progressive education was considered to have influence in ongoing Swedish folk school reforms:

We have had curriculum reforms; in 1919 we had a very important reform in the public school with the new curriculum that was very radical, it was very much influenced by progressive ideas, especially from Germany, but also from America. (SWE I1)

Besides pedagogical ideas, state-assigned delegations also imported new ideas about organising schooling. In Norway, ideas were collected from Scotland, Germany and France, while in Finland, faces turned to Sweden, mainly due to the co-operation of the Nordic Social Democratic movement.

So, during the 1930s and '40s we had delegations to other countries. Scotland, Germany and so on where they had inspiration, they learned about how to organise education. They came home, and they had written reports from their observations and these reports were then part of the discussions before they decide on how to establish new legislation. (NOR I1)

In Norwegian narratives, the start of the Second World War saw the end of many reforms that were planned, like the seven-year folk school. In Norway, which was occupied by the Germans in the 1940s, the resistance to the Nazi regime had a strong symbolic meaning in the narratives. According to some reflections, the resistance embedded prestige and an autonomous status not only for the State, but also for Norwegian schools and teachers. In Finland, which was fighting beside Germany against the Soviet Union, the aftermath of the war was more difficult, as the nationalistic content and spirit of school education was replaced by new citizen ideals. In all three countries, the end of the Second World War also meant the end of Germany as a reference society. Instead, faces were now turned westward, towards the United States, especially in the Swedish case. This was shown both in foreign language preferences and in new ideas on schooling and education.

At that time after the war, the war meant that the links to Germany were cut. Before the war, the first foreign language was German, English was the second. After the war English 
was first and then came German and French. So, the general interest in the education system in teacher education and so on, turned its faces West. (SWEI1)

Nordic educational progressivism, previously inspired by German philosophy, started to lean more on the ideas of American pragmatism and military psychology, making the question of educability a question of experiments, statistics and measurable learning. The new way of framing educational problems as a question of science-based state planning also provided an impetus for the emerging Nordic comprehensive school. The Swedish interviewees generally did not mention other countries as influential in the creation of their comprehensive school. One could argue for two parallel narratives in the Swedes' reasoning behind the comprehensive school reform taking place in 1950s. On the one hand, comprehensive school was presented as a social democratic programme, with the intention of improving social and educational equality. On the other, the new comprehensive school was presented as a solution to streamlining the problematic administration.

But my notion is that when you built up Sweden, modern Sweden with lots of state involvement in many ways and also detailed rules and systems, this change was rather a Swedish thing. I think it was not so much influenced from the outside. That's ... it was rather how do you take a new step to handle the new situation of modern Sweden? (SWE I4)

The task of this committee was basically to try to find something new, not a comprehensive school. That was not the idea of that committee, but rather to tidy up in a way, to get some order into this jungle of school reforms. (SWE I3)

After the Second World War, in Norway and in Finland the Social Democratic Party started slowly to regain power in state matters. Re-established political co-operation between the Nordic social democratic parties meant a growing influence for Sweden in both Finland and Norway. For both Finland and Norway, Sweden was a place to look for new ideas to modernise society and boost the economy by means of education. During the 1950s and 1960s Finland and Norway followed both the Swedish idea of research and experimental development practices, as well as the contents and structure of the education system.

Then we have the period in which we do what the Swedes do. We followed the Swedish [model] for reforming schools. Ten years after this. Always ten years behind. That's true. (NOR I1)

\section{From pan-Nordic egalitarianism to global knowledge economy}

The second transformation period begins from the situation in which all three countries have adopted the idea of a nine-year comprehensive school model. The reforms proceed at a different pace in each country: Sweden implemented the comprehensive school system in 1962; Norway followed in 1969; while Finland started up the five-year implementation period of the 1968 comprehensive school act in 1972.

In all three countries, the comprehensive school system was intended to increase the general level of education and prevent students' educational opportunities being defined by geographical or socio-economical differences. The State ensured this by extending the length of compulsory education and by governing schools through regulations, inspections and central planning. The comprehensive school extended education to the whole generation and was thus considered as a way to increase human capital in addition to being a vehicle for social mobility. 
The new school model was accompanied by a torrent of new theoretical and pedagogical ideas. In Norway and Finland, the 1970s were thus considered to be a golden time for leftist and Marxist education politics characterised by a strong belief in the future and social change. In Norwegian narratives the influences were coming from Danish radicalism while in Finland there was also official cooperation with socialist countries such as the German Democratic Republic.

Surely Sweden was the one that was being followed [...] but influences also came from GDR and it showed also in teacher education: the only international expert in 1973 teacher education committee was from East Germany [...] The University even eschewed comprehensive school a little because it contained so much of this kind of leftist rhetoric. (FIN I4)

While scholars were importing and exporting ideas of how social equality could be reached through education, political actors and especially economists had already started to worry about how schools could contribute to economic growth. In all three countries, the critique of the comprehensive school assumed that schools were not educating the right kind of work force. Here again, Sweden was the first in line. Having not taken part in the Second World War, the Swedish economy had a head start compared to many of its European neighbours. After the war, Sweden enjoyed a growing economy for several decades. Coming up to the late 1970s, however, other countries began to catch up, which in the Swedish narrative marks the beginning of this transformation period. Feeling like they had lost their competitive edge, Sweden was compelled to consider the cost of a welfare state education system.

This was a time when there started to be more economic pressure, economic challenges from the oil crisis in the beginning of '70s because the ' 50 s and the ' 60 s had been what we call rekordår [record years]. It was national growth all over so the state income grew, everything grew. Industrial development just flourished et cetera. So, this was a little break. And perhaps it had something, some influence to find new ways, more flexible even for state. (SWE I4)

According to the Swedish and Finnish stories, the first critique of the comprehensive school came from the business sector and was supported by the media in the early 1980s. Employers' organisations became more vocal about how the public sector should be run. In both Sweden and Finland, schools were criticised for equalising pupils too much, while in Norway the critique was more about the inefficiency of the school system as whole. In Finland, the critique of the school system started almost before the comprehensive school reform was completed: an Ability grouping, a relic from the previous parallel school system which had produced educational dead-ends in the selection for upper secondary education, was not abolished until 1985.

In Sweden, some private sector actors were described as driving the discussion towards a more deregulated and privatised system. Excluding the few mentions of international influences like Ronald Reagan's 'Nation at Risk' report and England, the independent school (friskola) system in Sweden was mainly described as a domestic invention establishing a quasi-market and promoting individual school choice was a rational, albeit criticised solution to the perceived decline of the quality of education. According to the stories, Finnish, Norwegian and Swedish politicians from both left and right started to place more stress on the importance of economic growth, cost-effectiveness of public services and state competitiveness. On the one hand, decentralisation policy and the municipalisation of 
educational administration in both Finland and Sweden emphasised local autonomy, but on the other hand this also created space for the specialisation and differentiation of comprehensive education. In Norway, the state was still pulling the administrative strings, but simultaneously the state signed up for an OECD evaluation to learn how to get more out of education. In many stories, Anglo-American economic liberalism, and the 'more with less' principle, were presented as a threat to the Nordic welfare model and egalitarian school system. In both the Norwegian and Swedish stories, this was also the point at which outside influence started becoming clearer, although the tendency still was to speak of ideologies rather than specific reference countries.

So, in that sense or at that time I think there were strong influential ideas from USA and even Great Britain from Reagan and Friedman, what we called new public management ideas. [...] And the new story was that we cannot go that way, just raising the budgets. We must evaluate. We must see how to get more out of the money. (SWE I4)

According to the stories, the competitive economy changed the way public organisations were governed and financed. On the one hand, changes were made in the spirit of democratisation to increase local and professional autonomy, but on the other, decentralisation was also a way to instal self-governing techniques of new public management at the local level. Decentralisation was considered to be more radical in Sweden and Finland, while in Norway, the state still retained the main responsibility for matters of education.

I'm not certain when they started and how, but I think this is a history that is quite different from the Norwegian example. So, there were lots of forces, there were discussions regarding the need for decentralisation, the need for specialised schools, the need for functioning schools. The kind of collapse of the idea of too much centralisation somehow. (SWE I6)

The deep economic recession of 1990-1993 had a special role in the Finnish narratives. The stories shared the idea that the most radical policy outlines to implement marketdriven mechanisms in the Finnish school system were buffered because of the weak economic situation. However, the budget cuts also set bounds for school development such as teacher training or evaluation practices. The special features of the Finnish evaluation policy (no school inspection, low-stake testing and teacher autonomy) were articulated through the intertwinement of cost-effectiveness and especially the trust in the local actors in the decentralised system, antithetic to the British system:

Like the Asians, they just didn't believe it. Ten years ago, on many occasions, many foreigners said that this guy must be lying, that we don't have school inspectors and the teachers really are allowed to decide the content of their teaching. In comparison to the British system where every single class on a given day do the same mathematics. This is the reality, these are the two extremes. (FIN I6)

At this point, transnational actors such as the OECD and the European Union (EU) started to appear in the narratives, even if with different emphases. According to the informants, joining the European Union in 1995 did not have major effects on the Finnish comprehensive school policy. Similarly, the role of the OECD was not highlighted in the Finnish interviews. Instead the role of Nordic co-operation was still considered to be important. As one interviewee summed up, 'the Finnish scope opened up in the 90s to the rest of Europe 
as well, but in educational issues the Nordic cooperation has always been at another level, very flowing, mutual and open to sharing ideas and experiences' (FIN I8).

Besides being observed as a national adaptation strategy of global economics and transnational policy drifts, the new transnational networks offered a platform for sharing knowledge and, more importantly, it was a technique to place oneself in relation to other countries. For Sweden, which had been an international policy model and an important actor in both the Organisation for Economic Co-operation and Development (OECD) and the United Nations Educational, Scientific and Cultural Organization (UNESCO) for decades, this was nothing new. But in Norway, the situation was different: huge investments that the state made in schooling caught wider international attention. As a fine example, all the Norwegian interviewees repeated almost verbatim that in the 1990s, 'we sincerely thought that we had the best education system in the world those days' (NOR I1 - NOR I18). At that time, the urge to be in the international spotlight was not so much considered as marketisation of the Norwegian school system, but as a cultural contribution to world society. Thus, the 1990 s were not only about being influenced by international policy drifts; it was also a time for making oneself visible to the world.

Another hindsight that both Finnish and Norwegian narratives took considering the 1990s was that Sweden was then starting to lose its position as the ultimate Nordic model country and it soon turned into a reference country for examples of both good and bad.

And what is essential I think, around 1994-95, was the decision [we made]. As in Sweden even more clearly, we had this diversification in the society and more pressure growing for school choice, too. But we made a different choice. In Sweden, they brought in more private schools alongside the public schools, a conscious choice to build this independent school concept. [...] And we made the choice that we wouldn't take this road. Instead, we would increase choice inside the public school system to release the pressure and to avoid the emergence of a twofold system. Because there are a lot of examples in the world you see, it's hard to have private and public education, how do I say, equal. (FIN I10)

\section{From the PISA shock to the delicate managing of future risks}

The third transformation period starts from the situation in which all three countries start to become estranged from the shared Nordic comprehensive school model and develop their own school models more locally and in reference to the global knowledge economy. Measuring countries according to various international indicators also causes concern about how one appears to others. In this world situation, the first PISA results were published in 2001. Against all odds, Finland had scored higher than the other Nordic countries.

In Finnish stories, the unexpected top position quickly created many explanations: every stakeholder wanted to have their share of the success. Most importantly, PISA was given a special meaning for muting the critique of inefficient schools and saving the comprehensive school model from market-oriented pressures. PISA showed that it was possible to achieve high learning outcomes without a harsh testing culture.

We have had here, for example, Koreans and Japanese and I must say that it's something we would not like to see so much here, this teaching-to-the-test culture and pupils sitting in the school almost all year, having only one-week holiday or so. And when some get 
exhausted there are always new to come. So, our strategy as a small country must be different from these intensive production units. (FIN I2)

After being bettered in the PISA results, the previous attitudes and change of relations to other Nordic countries were reflected openly in the Swedish interviews.

You have to remember, when I went to school in the '70s the cleaning ladies and the women that served us food were from Finland. They were immigrants in Sweden having the lowest paid jobs. And we were thinking of ourselves as the big country in the Nordic region. We were the ones that had the Nobel Prize. [...] But we were considering Finland and Norway and Denmark and Iceland as our little brothers. And then Finland came out on top of us [....] It changed how we look at our neighbours. And I think this Finnish miracle really hurt our souls in some way [laughter]. (SWE I12)

While the Swedes were relatively satisfied with the first PISA results, the same cannot be said about the Norwegians. According to many stories, the former Minister of Education, Kristin Clemet, gave a speech right after the PISA results were published in autumn 2001. Contrasting the situation with cross-country skiing - in which Norway and Finland are passionate competitors - Clemet had said: 'This is like coming home from the Winter Olympics in cross-country skiing without one single Norwegian medal. And this time the Finns weren't drugged ${ }^{4}$ (NOR I16). In order to improve the results in future, Norwegians started to look at ideas from well performing countries. However, what surprised the Norwegian policymakers was the general lack of understanding of how to achieve better learning outcomes.

And of course, you also had what could be called PISA envy because we saw that the Finns were on top and we didn't understand why the Finns were coming out on top. I'm not sure the Finns understood it themselves. (NOR I18)

Besides the changing internal relationships between national actors and between the Nordic countries, PISA also brought new reference countries into Nordic education politics. While the United States and England were described as the home of neoliberalism to be avoided, Canada began to be seen as a more Nordic-like nation and, more importantly, it had been doing very well in PISA assessments. In most stories, the Western context was considered to be very important for policy borrowing, while in some reflections, all countries could be potential places for learning, or should at least not be overlooked. Moreover, the references were not constructed only between the countries but also between regions within countries, like municipalities and provinces. This trans-local co-operation was considered to be important in order to gain trust between schools, administration and the political system.

So, if it had only been countries like China or Singapore or that kind of country then we perhaps would have a different debate. But we have countries like Finland and provinces in Canada and we have Australia or the Netherlands and countries that are in a way very similar to us. We like the policy, we like the culture and they are doing it better than us. So, can we learn something from them? (NOR I14)

Another thing which PISA turned upside down, at least in Norway and Finland, was the 1980s and 1990s discourse about the efficient and specialised private versus the homogenous and inefficient public education. While interviewees in Sweden either defended or reluctantly accepted the idea of independent schools and profit making, 
many Norwegian and Finnish interviewees criticised the Swedish independent school (friskola) system for getting 'less with more', and that privatisation of public education should not occur in their own countries. This critique was often presented when problematising the 'edu-business' in terms of social differentiation and tension between public good and private profit making.

We don't want to see the same happening with the Norwegian school system like in Sweden.... Corruption and money in island states.... Bahamas ... taxpayers' money. And what about when they go bankrupt? (NOR I8)

Many Swedish informants recognised that having private education providers with no limitations to profit making was problematic, as was the fact that Sweden is 'the only country in the world allowing this' (SWE I6). On the other hand, it was clear that it would not be at all simple to do away with private providers altogether.

It's the same with the independent schools. The government can't just take over them. They have to buy them. So first we gave away, the taxpayers gave away. And now we have to pay for them to give them back. We gave them away but we have to pay to get them back. And it's economic suicide. It's impossible. (SWE I12)

Another factor that was often discussed when describing the ideal school system was highly educated and trusted teachers. In Sweden, teachers had been subjected to criticism from long before PISA, but declining ranking in international competition re-fuelled the discussion of the quality of teaching. Having taken decentralisation quite far, the state now had to create new mechanisms to ensure that teachers and schools were doing their job. This was done by implementing 'more testing, and also more data collection' (SWE I7). When the Swedish informants reflected on the present state of the teacher profession, it was clear that appreciation of the teaching profession had become a big challenge for the whole school system over the years. The status of Swedish teachers was described as being 'far, far away from Finland' (SWE I11). In terms of assessment and evaluation, Swedish teachers were also estimated to be 'assessed and controlled much more' (SWE I3) than their Finnish colleagues.

A similar trend can be recognised in Norway. Until the 1990s, Norwegian teachers were said to have had lot of power in both schools and in education politics. The tightening assessment culture was considered to decrease the professional autonomy of teachers. The current problem for Norwegians was how to include teachers and classroom practices as active agents of research-based reforms, but not as political objects.

While both Norwegians and Swedes often mentioned Finland when speculating about how the autonomy of teachers and teacher education could be improved in their countries, the Finns themselves did not always seem to appreciate their own teacher education. In addition to the educational stagnation caused by the first PISA results, the declining PISA results from 2006 concerned many Finns as well.

People say that the Finnish teacher education system is at the top of the world. Well, it is not. There is lot of fixing there. Instead of this current system where we think that teachers are ready when they graduate from university, we should see that professional development is continuous. (FIN I6)

Besides a settled practice that takes place every third year, PISA was also observed as a threat to education systems by disregarding national features and by emphasising international 
standardisation, competition and cost-effectiveness in terms of economic inputs and learning outputs. In some reflections, PISA was also considered to be losing its novelty in politicking on the future. New 'still unknown but yet imaginable' future prospects have already started to fight for political attention within PISA. These prospects are related to globalisation, future competence and increased technology in education.

And our systems are really national. In the EU, you mustn't touch the education systems at all. That's in the legislation from the EU. Still we have this internationalisation which is so strongly impacting nations. I think it's rather interesting. But nobody knows what the next step will be. Probably we will continue to have international testing, I could see. [...] We talk about prestige. We talk about it as kind of Olympic Games. How do we compete with other countries? (SWE I4)

If you look at the labour market, we will need people with general competencies but we will also need people with social and emotional skills that could work in teams and all that. And then we also need students that develop deep expertise related to domains and so on. And I think we need to tailor our systems so it could adapt to these three challenges. (NOR I15)

One thing that was frequently considered as deciding the course of the future was the relationship between economic growth, socio-regional differentiation and globalisation. The question was how the comprehensive school can combine the various expectations related to economic growth, social justice and cohesion, trust in democracy and education itself. Possible futures and the risks and opportunities they may entail also lead to more delicate wordings and careful estimations of what the future might hold. However, avoiding educational inequalities and social segregation are crucial in order to maintain Nordic democracy.

$[\mathrm{H}]$ ow we look at education and also how young people look at each other and, that's why I think I'm so scared about the American election actually. It takes many years before we see a Trump, many years of their lack of education. They're not interested in education. They are also outside the market, [that is] they are not working. Generation after generation. And then something happens with democracy and the way you look at the elite et cetera. (SWE I5)

\section{Discussion}

In this article, we have analysed the narratives of comprehensive schooling and the use of reference countries produced by educational experts in three Nordic countries: Finland, Sweden and Norway. In the narratives, we recognised three transformation periods during which the relationships to external reference societies change. In these transformations, new countries emerge, and previous ones fade away, or a given country is seen in a new way. Figure 1 assembles three timelines in terms of temporal, social and factual dimensions. It presents the moving landscape of reference countries across different time periods, showing country influences that appear and fade away, as well as the way these influences are observed (preferred $=+$ /avoided $=-$ ).

Despite the country-specific differences, some mutual trends can be recognised. At the beginning of the first transformation period, pedagogical ideas and models for organising education were borrowed from various European countries and at a range of paces. Since the stories often emphasise the importance of the Protestant church for the 
birth of folk education, the important countries would then implicitly refer to the Nordic countries, Germany and Great Britain. In Sweden, industrialisation played an important part in the early reformation, while the Norwegian and Finnish narratives discussed education reforms in terms of nation building. The Second World War changed this pattern. After the war, Germany turned from the borrowing platform into an unusable reference country and the West became an important direction for not only seeking new ideas, but also for co-operation, and a place for recycling pedagogical ideas originating from Germany. Simultaneously, Norway and Finland started to look towards the Swedish school model to modernise their own systems, while in Sweden, international influences were no longer playing any part.

The second transformation period followed a pan-Nordic period in which changes happened first in Sweden and later in Norway and Finland. In all three countries, Sweden was considered the ultimate reference country, the one that was admired and followed until the 1990s. From the late 1980s, however, the meaning of international influences started to change, and the pan-Nordic project of social inclusion started to search for models of how to do more with less. Instead of following a specific country, the general interest seemed to be on how different countries survive in changing world situations. This change was mainly described in terms of increasing economic globalisation, new public management or an increasing role of transnational organisations.

In contrast to the first two previous periods, all three countries started the third transformation period at the same time, right after PISA 2001, which increased the number of reference countries. Well-performing and culturally suitable reference countries, such as Canada and Finland, started to receive positive attention in the stories. Instead of a single pedagogical or organisational solution, success or failure in PISA is understood to be the sum of many factors, such as societal trust in teachers, moderate

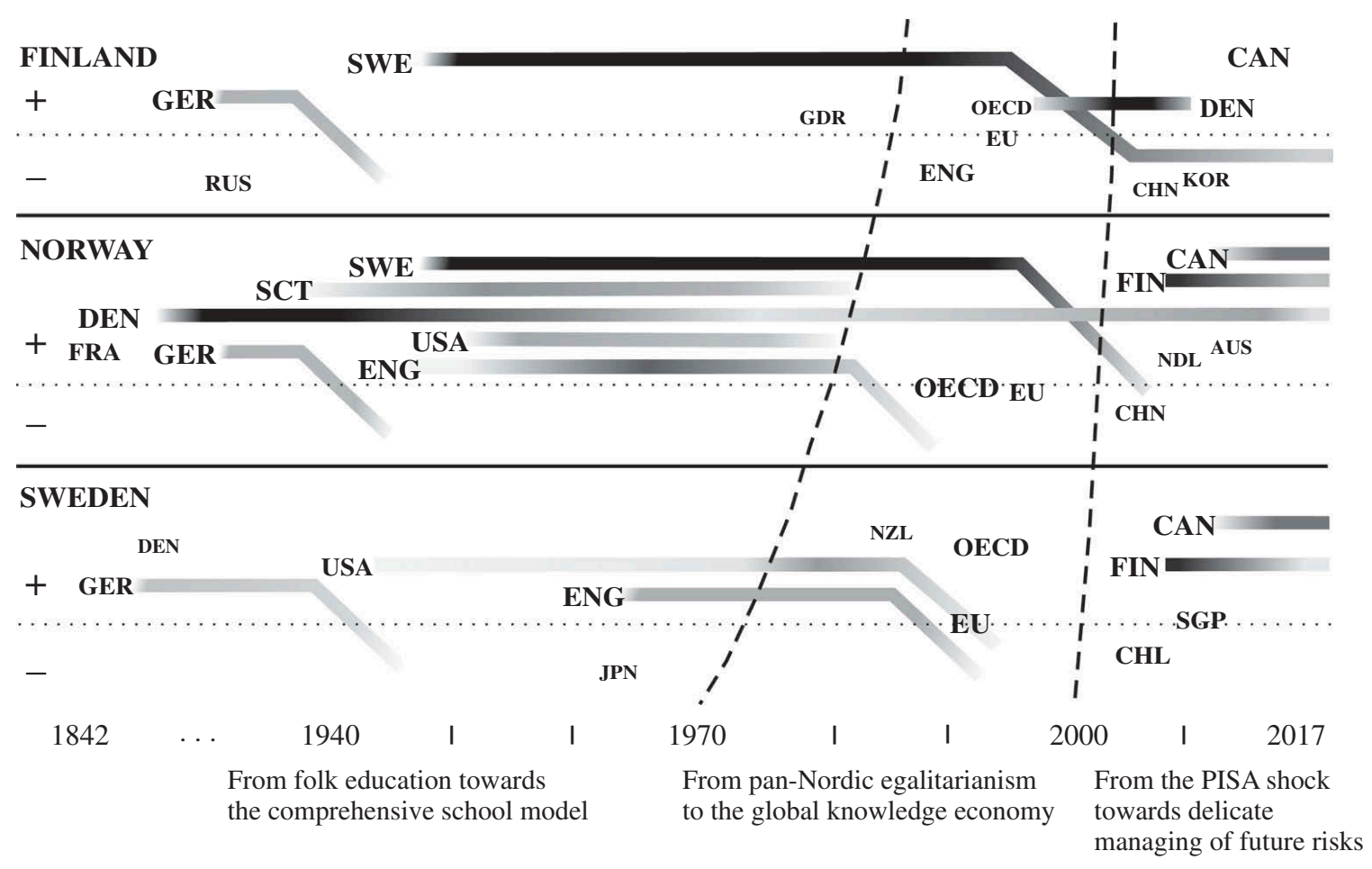

Figure 1. Changing reference societies in the narratives of educational experts. 
reform policy and well-organised special education. However, as moving towards the present moment and future challenges, the role of PISA as an indicator of the ideal school system has come to be questioned more and more. As a result, other countries are no longer observed as much as models to follow. Rather, they are more like a hall of mirrors in which one's educational hopes and fears can be reflected.

The narratives of educational experts seem to conform many earlier countryspecific studies on the development of Nordic 'school for all' model, where unified social democratic consensus and strong state planning is reached by the 1960s, but then drastically differentiated by supra-national economic forces emerging in the late 1980s (see Arnesen et al. [2014]; Telhaug, Mediås, and Aasen [2006]; Antikainen [2006]). Our findings also support earlier notions of Sweden's changing self-image from the self-sufficient forerunner and silent borrower (Ringarp and Waldow 2016) towards late PISA-shock and more explicit borrowing (Tveit and Lundahl 2018) as well as the contradictory and metaphoric usage of PISA when either resisting or legitimising national reforms (Takayama 2008; Tveit 2014).

One must keep in mind that the use of reference countries is always connected to the constantly changing relational dynamics between the referrer and the referred. As previous research has pointed out, the use of external reference countries can also be very flexible. A specific event, a policy programme or a PISA score may lead to different interpretations, not only across the countries but even within a single country (Takayama 2010). Whether intentional or not, finding solutions from elsewhere by idealising the other and scandalising the self (see Waldow, Takayama, and Sung [2014]) can lead to unpredicted consequences, such as degeneration of trust between schools, teachers and parents or research and business life. Similarly, demonising others might work towards protection of the self, but simultaneously mutes well-grounded criticism.

As research literature on educational borrowing and lending emphasises, the best practices' are more likely to be adopted or treated as useful if they fit the domestic policy agenda (Steiner-Khamsi 2014; Takayama 2010). We share the idea within the notion that these preferable model countries should not only fit the policy agenda, but also resonate with the domestic cultural and societal aspects of educational and pedagogical values (see Waldow [2017]). The clearest evidence backing this argument in our data was stated in the Finnish interviews, in which the Asian top PISA countries (South Korea, Shanghai, Hong Kong) were described as 'intensive production units'. The top scores of these 'Asian tigers' (see Waldow, Takayama, and Sung [2014]; Sellar and Lingard [2013]) are not worth aspiring to, because their results are being reached with questionable means, e.g. a hierarchical teacher-pupil relationship, ten-hour school days and mechanistic learning (many times referred to as 'teaching to the test') - all more or less vague cultural images with weak evidence but with a strong message. Simultaneously, it seems that Canada has recently become an educational attraction, even among the Nordic countries. Interestingly, in the narratives it seems to be unnecessary to point out explicit features of the preferable Canadian practices. Instead the attraction and the possible borrowing takes place within the limited Western culture, which suits Nordic educational traditions particularly well. 


\section{Conclusion}

Approaching the development of a Nordic comprehensive school system through the narratives opens up a new perspective in the study of educational borrowing and lending. Whereas the previous reference country research has focused mainly on analysing historical policy documents, our study raises attention on how the sociohistorically constructed images between close 'neighbours' become strategically used and reinforced in everyday communication. These narratives combine and filter different pieces of past-related information such as research results, media feeds, anecdotes, stereotypes and personal experiences. The images of shared values and histories do not only increase the possibility of policy borrowing and lending, but they also invoke emergencies: what has happened to our neighbour could also soon happen to us.

As a fine example, in their stories, the Finnish and the Norwegian interviewees adopted a strict negative attitude towards the privatisation policy of the Swedish education system, which in some cases has led either to school closures due to bankruptcy, or improper connections to tax havens. Even though these experiences might be extreme cases in the big picture, they provide a powerful argument against similar privatisation and marketisation pressures in Finland and Norway. Similarly, recent media discussions in which Swedish experts warn their policymakers not to follow Finland's reforms (Dagens Nyheter 2015), represents the flexibility of the use of reference societies in public discussions. In addition, 'the Swedish warnings' are also used in Finnish media to criticise ongoing reforms in Finland and as a suggestion of reverting to 'good old methods' and more systematic assessment (HS. Helsingin Sanomat 2018). It should also be noted that the further back in history the narratives go, the more they have been learnt rather than experienced first-hand. It is perhaps easier to see more sides to the current debates than in occurrences decades or even centuries back when our informants were not yet active in their fields. Despite the growing criticism, we cannot understate the role of the international large-scale assessments such as PISA as an ultimate frame setter in current twentyfirst-century educational narratives. However, when discussing the future, many of our interviewees pointed out global challenges such as humanitarian crises, migration, environmental issues and tensions across the superpowers with the overwhelming rise of posttruth politics, all of which create complex and often unpredictable patterns in a world in which education systems should reciprocally work as a platform of predictability and a better future. So far, the Nordic education systems themselves have been treated relatively successfully in combining educational achievement and equality nationally. Which countries will emerge as the preferred educational reference countries tackling these future challenges remains to be seen. The landscape is constantly changing, thus the observations and notions presented in this paper may also be of interest in the decades to follow.

\section{Notes}

1. Re-enactment refers here to Collingwood's idea of how the past is implicated in the present.

2. Seeing one's future in others' present is important for policy borrowing, while seeing others' future in one's own present is important for policy lending (Hansen, Thostrup, and Sivesind 2017). 
3. N.F.S. Grundtvig (1783-1872), an influential Danish philosopher and the father of the folk high school.

4. Earlier in 2001 in the FIS Nordic World Ski Championships in Lahti, Finland, six athletes from Team Finland had been disqualified for using performance-enhancing drugs.

\section{Acknowledgements}

We thank the editors and the two anonymous reviewers for their valuable suggestions that have advanced the progress of this article. We also gratefully thank all people who have participated in this study.

\section{Disclosure statement}

No potential conflict of interest was reported by the authors.

\section{Funding}

This work was supported by the Academy of Finland [276221];

\section{ORCID}

Petteri Hansen (D) http://orcid.org/0000-0003-2209-3618

Tommi Wallenius (D) http://orcid.org/0000-0003-0956-5254

Sara Juvonen (D) http://orcid.org/0000-0003-2798-9376

Janne Varjo (D) http://orcid.org/0000-0003-2528-4241

\section{References}

Ahonen, S. 2014. “A School for All in Finland." In The Nordic Education Model: 'A School for All' Encounters Neo-Liberal Policy, edited by U. Blossing, G. Imsen, and L. Moos, 77-93, Dordrecht: Springer. (Policy Implications of Research in Education)

Andersen, N. Å. 2003. Discursive Analytical Strategies: Understanding Foucault, Koselleck, Laclau, Luhmann. Bristol: Policy Press.

Andersen, N. A. 2008. Partnerships: Machines of Possibilities. Bristol: Policy Press.

Andersen, N. A.. 2013. "Luhmann and Koselleck: Conceptual History and the Diagnostics of the Present." In Luhmann Observed, Radical Theoretical Encounters, edited by A. La Cour and A. Philippopoulos-Mihalopoulos, 203-224. London: Palgrave Macmillan.

Antikainen, A. 2006. "In Search of the Nordic Model in Education." Scandinavian Journal of Educational Research 50 (3): 229-243. doi:10.1080/003138306007.

Arnesen, A.-L., E. Lahelma, L. Lundahl, and E. Öhrn. 2014. "Unfolding the Context and the Contents: Critical Perspectives on Contemporary Nordic Schooling." In Fair and Competitive? Critical Perspectives on Contemporary Nordic Schooling, edited by A.-L. Arnesen, E. Lahelma, L. Lundahl, and E. Öhrn, 1-19. London: Tufnell Press.

Blossing, U., and Å. Söderström. 2014. "A School for every child in Sweden." In The Nordic Education Model: 'A School for All' Encounters Neo-liberal Policy, edited by U. Blossing, G. Imsen, and L. Moos, 17-34. Dordrecht: Springer. (Policy Implications of Research in Education).

Dagens Nyheter, D. N. 2015 April 21. "Finland är inget föredome. Skolframgångarna feltolkas." A daily newspaper in Sweden 
Dovemark, M., S. Kosunen, J. Kauko, B. Magnúsdóttir, P. Hansen, and P. Rasmussen. 2018. "Deregulation, Privatisation and Marketisation of Nordic Comprehensive Education." Education Inquiry 9 (1): 122-141. doi:10.1080/20004508.2018.1429768.

Esping-Andersen, G. 1990. The Three Worlds Of Welfare Capitalism. Cambridge: Polity.

Hansen, P., R. Thostrup, and K. Sivesind. 2017. "Managing Expectations by Projecting the Future School - Comparing the Semantics of National Future Reports on Basic Education in Denmark, Finland and Norway". Unpublished conference paper, ECER, Denmark.

HS. Helsingin Sanomat. 2018 April 24. "Ruotsalaistutkija varoittaa: Suomi toistaa uudessa opetussuunnitelmassa Ruotsin virheet". A daily newspaper in Finland

Imsen, G., and N. Volckmar. 2014. "The Norwegian school for all: Historical emergence and neoliberal confrontation." In The Nordic Education Model: 'A School for All' Encounters NeoLiberal Policy, edited by U. Blossing, G. Imsen, and L. Moos, 35-55. Dordrecht: Springer. (Policy Implications of Research in Education).

Joas, H., and W. Knöbl. 2009. Social Theory: Twenty Introductory Lectures. Transl. Skinner, A. Cambridge: Cambridge University Press.

Lindblad, S., and T. Popkewitz. 2000. "Public Discourses on Education Governance and Social Integration and Exclusion. Analyses of Policy Texts in European Contexts." Uppsala Reports on Education, nr 36.

Luhmann, N. 1992. "Operational Closure and Structural Coupling: The Differentiation of the Legal System." Cardozo Law Review 13: 1419-1441.

Luhmann, N. 1995. Social Systems. Stanford: Stanford University Press.

Lyotard, J. F. 1979. The postmodern conditions: A Report on Knowledge. Manchester: Manchester University.

Meyer, J. W., J. Boli, G. M. Thomas, and F. O. Ramirez. 1997. "World Society and the Nation State." American Journal of Sociology 103 (1): 144-181. doi:10.1086/231174.

Moos, L. 2009. "Hard and Soft Governance: The Journey from Transnational Agencies to School Leadership." European Educational Research Journal 8 (3): 397-406. doi:10.2304/eerj.2009.8.3.397.

Noy, C. 2008. "Sampling Knowledge: The Hermeneutics of Snowball Sampling in Qualitative Research." International Journal of Social Research Methodology 11 (4): 327-344. doi:10.1080/ 13645570701401305.

Rhodes, R. A. W. 2011. Everyday Life in British Government. Oxford: Oxford University Press.

Ringarp, J., and F. Waldow. 2016. "From 'Silent Borrowing' to the International Argument Legitimating Swedish Educational Policy from 1945 to the Present Day." Nordic Journal of Studies in Educational Policy 2016 (1): 29583. doi:10.3402/nstep.v2.29583.

Schieder, T. 1978. "The Role of Historical Consciousness in Political Action." History and Theory 17 (4): 1-18. doi:10.2307/2504707.

Schriewer, J. 1990. "The Method of Comparison and the Need for Externalization: Methodological Criteria and Sociological Concepts." In Theories and Methods in Comparative Education, edited by J. Schriewer and B. Holmes, 25-83. Frankfurt am Main: Peter Lang.

Schriewer, J., and C. Martinez. 2004. "Constructions of Internationality in Education." In The Global Politics of Educational Borrowing and Lending, edited by G. Steiner-Khamsi, 29-53. New York: Teachers College Press.

Sellar, S., and B. Lingard. 2013. "Looking East: Shanghai, PISA 2009 and the Reconstitution of Reference Societies in the Global Education Policy Field." Comparative Education 49 (4): 464485. doi:10.1080/03050068.2013.770943.

Simola, H., J. Kauko, J. Varjo, M. Kalalahti, and F. Sahlström. 2017. Dynamics in Education Politics: Understanding and Explaining the Finnish Case. London: Routledge.

Sørensen, E. 2006. "Metagovernance: The Changing Role of Politicians in Processes of Democratic Governance." The American Review of Public Administration 36 (1): 98-114. doi:10.1177/0275074005282584.

Stäheli, U. 1997. "Exorcising the Popular Seriously: Luhmann's Concept of Semantics." International Review of Sociology 7 (1): 127-145. doi:10.1080/03906701.1997.9971228. 
Steiner-Khamsi, G., ed. 2004. The Global Politics of Educational Borrowing and Lending. New York: Teachers College Press.

Steiner-Khamsi, G. 2014. "Cross-National Policy Borrowing: Understanding Reception and Translation." Asia Pacific Journal of Education 34 (2): 153-167. doi:10.1080/02188791.2013.875649.

Takayama, K. 2008. "The Politics of International League Tables: PISA in Japan's Achievement Crisis Debate." Comparative Education 44 (4): 387-407. doi:10.1080/03050060802481413.

Takayama, K. 2010. "Politics of Externalization in Reflexive Times: Reinventing Japanese Education Reform Discourses through 'Finnish PISA Success'." Comparative Education Review 54 (1): 51-75. doi:10.1086/644838.

Telhaug, A. O., O. A. Medias, and P. Aasen. 2006. "The Nordic Model in Education: Education as Part of the Political System in the Last 50 Years." Scandinavian Journal of Educational Research 50 (3): 245-283. doi:10.1080/00313830600743274.

Tveit, S. 2014. "Educational Assessment in Norway." Assessment in Education: Principles, Policy \& Practice 21 (2): 221-237. doi:10.1080/0969594X.2013.830079.

Tveit, S., and C. Lundahl. 2018. "New Modes of Policy Legitimation in Education: (Mis)Using Comparative Data to Effectuate Assessment Reform." European Educational Research Journal 17 (5): 631-655. doi:10.1177/1474904117728846.

Waldow, F. 2009. "Undeclared Imports: Silent Borrowing in Educational Policy-Making and Research in Sweden'." Comparative Education 45 (4): 477-494. doi:10.1080/03050060903391628.

Waldow, F. 2017. "Projecting Images of the 'Good' and the 'Bad School': Top Scorers in Educational Large-Scale Assessments as Reference Societies." Compare: A Journal of Comparative and International Education 47 (5): 647-664. doi:10.1080/03057925.2016.1262245.

Waldow, F., K. Takayama, and Y.-K. Sung. 2014. "Rethinking the Pattern of External Policy Referencing: Media Discourses over the "Asian Tigers" PISA Success in Australia, Germany and South Korea." Comparative Education 50 (3): 302-321. doi:10.1080/03050068.2013.860704.

Wermke, W., and G. Höstfält. 2014. "Silent and Explicit Borrowing of International Policy Discourses. The Case of the Swedish Teacher Education Reforms of 2001 and 2011." Education Inquiry 5:4. doi:10.3402/edui.v5.23417. 